Furthermore, feeding in individual pens led to reduction of the variability of body composition criteria (variation coefficients reduced by $20 \mathrm{p}$. Ioo on an average). Thus, this method allows to increase the accuracy of young males testings at the station, as well as that of the measurements made during the feeding trials, without reducing the feed intake level of the animals.

2. Body composition traits estimated in this trial by means of various methods (measurement of fat thickness, weight of cuts, estimation of specific gravity) confirm the low carcass quality of ad libitum fed Large White pigs (loin/backfat ratio varying from I.5 to 2.2). Moreover, the $36 \mathrm{p}$. roo reduction of the carcass quality and $15 \mathrm{p}$. Ioo increase of the feed intake (corresponding to $3^{8} \mathrm{~kg}$ feed per pig) in the castrated males as compared to the non castrated ones (males or females) emphasize once more the economic loss resulting from castration of pigs from this breed.

\title{
Measurement of zootechnic performances in pigs subjected to a pre-fattening period of variable length
}

\author{
J. P. BOUARD and M. LEUILLET \\ Institut technique des Céréales et des Fourrages, \\ 8. Avenue du Président Wilson, \\ 75116 Paris
}

The purpose of this trial was to compare two rearing techniques for bacon pigs :

- classical rearing in one only piggery with restricted feeding;

- two rearing phases : a growing period with ad libitum feeding (pre-fattening) and a finishing period with restricted feeding in another piggery. The length of the pre-fattening periods was 28,42 or 56 days.

In our experimental conditions, the best technique from both a zootechnic and economic point of view is that based on the association of severe restriction during the finishing period and a long lasting pre-fattening period ( $4^{2}$ or 56 days), i. e. till a mean weight of $65 \mathrm{~kg}$.

\section{Maize and barley flaking and popping}

\author{
I. - Processing \\ II. - Flaked Maize digestion in the growing Pig
}

L. P. BORGIDA

Laboratoire de Technologie des Aliments des Animaux, I. N. R. A., C. N. R. Z., 78350 Jouy en Josas

\section{I. - Processing}

Steam flaking $\left(\mathrm{I}^{\circ} \mathrm{O}^{\circ} \mathrm{C}, 45\right.$ or $\left.55 \mathrm{mn}\right)$ and grain popping in $280^{\circ} \mathrm{C}$ heated air during $5^{\circ}$ seconds increases long chain soluble carbohydrate formation and intensify $\alpha$-amylase in vitro action upon starch.

Annales de Zootechnie. -- 1975. 


\title{
II. - Flaked maize digestion in the growing pig
}

In growing pigs, flaking of maize significantly improves $(\mathrm{P}<0,0 \mathrm{I})$ organic matter and espe. cially nitrogen digestibility of a balanced feed containing maize ( 87 or $8 \mathrm{I} \mathrm{p.} \mathrm{100)} \mathrm{and} \mathrm{fish} \mathrm{meal}$ $(6$ or 12 p. I0o), but it has only an effect on nitrogen retention, at the $\mathrm{I} 2 \mathrm{p}$. Ioo protein level $\left(+0.2 \mathrm{~g} \mathrm{~N}\right.$ retained $\left./ \mathrm{kg} \mathrm{W}^{0,75}\right)$.

In gut contents of pigs killed one or three hours after a test meal the following was noticed after flaked maize feeding :

- a higher water content in the gut,

- a much slower water flow from the stomach, where the $\alpha$-amylase activity was higher and the $\mathrm{pH}$ decrease later and more marked.

-- in the small intestine, starch degradation was intensive (ro to zo fold higher soluble carbohydrate concentrations) and could explain the higher water retention.

\section{Dynamies and hierarchy of vitamin A storage in the pig liver}

\author{
R. FERRANDO, A. RANDOLPH and P. C. BLIN \\ Laboratoire de Recherches de la Chaire de Nutrition et Alimentation \\ École nationale vétérinaire d'Alfort. \\ 94701 Maisons Alfort
}

In the pig, there seems to be a repletion hierarchy of the liver with respect to vitamin $\mathrm{A}$. The right lobe is the first one to be rapidly loaded and the Spigel lobe, the last one.

The percentage of vitamin A stored as compared to the dose ingested seems to be larger than in the rat. However, in the pig like in the rat, mean doses allotted over several days appear to be more efficient for liver storage than the administration of a single high dose. 